\title{
WHAT YOU DO TO CHILDREN MATTERS": TOXIC MOTHERHOOD IN TONI MORRISON'S GOD HELP THE CHILD
}

\author{
Manuela López Ramírez
}

University of Valencia (Spain)

\begin{abstract}
Toni Morrison's latest novel, God Help the Child, explores the damaging effects of racism on motherhood and the dramatic impact of toxic mothering upon children. The institution of patriarchal motherhood fails to enact the critical tasks of motherwork - preservation, nurturance and cultural bearing, while mothering is a potential site of empowerment of black children and African American culture. African American authoritarian parenting style, associated with patriarchal motherhood, has a correlation with diverse factors, such as the legacy of slavery and its survival strategies, low-income and/or single-parent households and the disruption of the motherline. Motherhood distorted by racism cannot develop a sense of black selfhood in children, thwarting their chances of survival, resistance and subversion of racist ideologies.
\end{abstract}

Keywords: African American, authoritarian parenting, passing for white, single, motherhood.

\section{Resumen}

La última novela de Toni Morrison, God Help the Child, explora los efectos dañinos del racismo sobre la maternidad y el impacto dramático de la maternidad tóxica en los niños. La maternidad patriarcal fracasa en las tareas críticas del 'trabajo materno'-preservación, nutrir, transmisión cultural, sin embargo los 'cuidados maternales' son una vía de empoderamiento potencial para los niños y la cultura afro-americana. La crianza autoritaria afro-americana, asociada a la maternidad patriarcal, tiene correlación con factores diversos como la herencia de la esclavitud, los hogares pobres y/o monoparentales y la ruptura de la línea materna. La maternidad distorsionada por el racismo impide el desarrollo de la identidad negra de los niños, frustrando sus posibilidades de supervivencia, resistencia y subversión de las ideologías racistas.

Palabras clave: afro-americano, crianza autoritaria, pasar por blanco, soltera, maternidad.

In her novels Toni Morrison develops a concept of black motherhood that is radically different from that of the dominant Western culture. Her picture of maternity contradicts the prevailing white notions of ideal motherhood. To fully 
understand Morrison's view of black motherhood, there are two key concepts defined by Adrianne Rich in Of Woman Born, "motherhood" and "mothering." Lauri Umansky, drawing from Rich's classification, points out that the oppressive and the empowering dimensions of maternity are mirrored in two competing feminist views on motherhood, the "negative" discourse that "focus[es] on motherhood as a social mandate, an oppressive institution, a compromise of woman's independence" and the "positive" one that postulates that "motherhood minus "patriarchy' ... holds the truly spectacular potential to bond women to each other and to nature, to foster a liberating knowledge of self, to release the very creativity and generativity that the institution of motherhood denies to women" (2-3). Thus 'motherhood' is a social and cultural construct, a patriarchal institution that controls, constrains and dominates women and their mothering in contrast to the non-patriarchal experience of 'mothering'. In her fiction, Morrison's positive approach to motherhood emphasizes the political dimension of black mothering, which defines motherhood as a site of power and resistance from which women can challenge racial oppression, "in loving her children the mother instills in them a loved sense of self and high self-esteem enabling them to defy and subvert racist discourses that naturalize racial inferiority and commodify blacks as other and object" (O’Reilly, Toni Morrison 11).

Morrison challenges the stereotypes of the black female, such as the conventional black matriarchal figures, protective and powerful, whose selflessness equates them to their nurturing qualities and annihilates the identity of the mother as an individual, properties that have traditionally been assigned to black women to justify their oppression and submission. Her portrayal of maternity conflicts with the socially-sanctioned views that idealize it: her mothers are active agents who transform and confront the harsh realities of a racial society. Morrison unveils the contradictions of black mothering, which does not abide by conventional standards. As Patricia H. Collins aptly argues:

African-American communities value motherhood, but the Black mothers' ability to cope with race, class, and gender oppression should not be confused with transcending those conditions. Black motherhood can be rewarding, but it can also extract high personal cost. The range of Black women's reactions to motherhood and the ambivalence that many Black women feel about mothering reflect motherhood's contradictory nature. (Black Feminist 133)

Morrison's oeuvre is crowded with atypical mother figures, which search for self-realization and self-worth in a world that has deprived them of these values. ${ }^{1}$

Morrison highlights the relevance of motherhood for the woman's

\footnotetext{
${ }^{1}$ In Sula, Eva Peace, Sula's grandmother, who in her god-like ways kills her own son, is a radical example of that.
} 
fulfillment in the African-American community and "for the emotional wellbeing of children because it is the mother who first loves the child and gives to that child a loved sense of self' (O'Reilly, Toni Morrison 178). She stresses the tar quality that women possess. In an interview with Judith Wilson, Morrison talks about Jadine, the main character of Tar Baby, and how, as a result of the impact of white values and ways of life, the ties with her African American ancestors have been sundered and she has lost the tar quality, "the ability to hold something together than otherwise would fall apart-which is what I mean by the nurturing ability" (31). In fact, mothers and motherhood are critical to African American culture, providing "the physical and psychological well-being and empowerment of African American people and the larger African American culture" (O’Reilly, Toni Morrison 4).

Morrison draws attention to the importance of 'othermothers,' "women who assist bloodmothers by sharing mothering responsibilities": "Biological mothers are expected to care for their children. But African and AfricanAmerican communities have also recognized that vesting one person with full responsibility for mothering a child may not be wise or possible" (Meaning 47). Hence, Morrison does not restrict maternity to its biological aspect. Surrogate mothers may even have a closer relationship with children than their birth mothers. As Andrea O'Reilly comments, “othermothering and community mothering, central to the institution of Black motherhood, are African American strategies of survival that make possible that children receive the mothering that ensures their psychological and physical well-being and makes their empowerment possible" (Toni Morrison 11).

Morrison's fiction expresses the complexities of maternity: in Beloved, the intense love of a mother, Sethe, that may lead her to commit infanticide, the hateful motherly crime, or to 'abandon' her baby so as to protect her in $A$ Mercy; the self-sacrificing, or even mutilation, and selflessness of a mother in Sula and Beloved, respectively; lack of positive mothering or toxic mothering (negligence or even abuse), resulting in the child's self-loathing, in The Bluest Eye; over-mothering a child, as Helene Wright with her daughter Nel in Sula; the importance of nursing as in Sethe's milk rape or Ruth Dead's nursing beyond infancy in Song of Solomon; raising children to acknowledge and celebrate their ancestors, Pilate Dead with her 'son', Milkman, in Song of Solomon; unconventional upbringing as Eva Peace does with her extended family in Sula. In her narratives, Morrison devotes special attention to womenonly households and single-mother families, which are often the consequence of males' desertion. ${ }^{2}$ Morrison also emphasizes the strong emotional bond between mother and daughter, who share the same predicament as objects of oppression in the white-dominated racist society. In her novels, both mother and daughter's

\footnotetext{
${ }^{2}$ Teresa N. Washington underscores the importance of the Àje mother-daughter bond in African culture, in which fathers are often "relegated to the outside" (173).
} 
perspectives are shown. We learn about what it is like to mother and what is like to be mothered (Daly and Reddy 2 ). ${ }^{3}$ In her rendition of mothering as a political and public enterprise, Morrison "emerges as a social commentator and political theorist who radically, through her maternal philosophy, reworks, rethinks and reconfigures the concerns and strategies of African Americans, and in particular black women's emancipation in America" (O’Reilly, Toni Morrison xi).

In God Help the Child, Morrison revisits a critical aspect of motherhood: how mothering is highly impacted by a racially-prejudiced society and the dramatic ensuing effects upon children, which she had already explored in her first novel, The Bluest Eye. In Sweetness, “who's been poisoned by that strain of color and class anxiety still present in black communities" (Walker 2015), Morrison personifies self-destructive and destructive/toxic modes of motherhood, which contrast with a positive mothering that includes

raising children in accordance with the values, beliefs, and customs of traditional African American culture and in particular the values of the funk and ancient proprieties. In each of these [maternal] taskspreservation, nurturance, cultural bearing-Morrison is concerned with protecting children from the hurts of a racist and, for daughters, sexist culture, and with teaching children how to protect themselves so they may be empowered to survive and resist the racist and patriarchal culture in which they live and develop a strong and authentic identity as a black person. (O’Reilly, Toni Morrison 29)

Sweetness is an inter-racial individual, whose marginal and tragic 'between two worlds' status makes her the victim of a race-conscious society. Unlike some of Morrison's mothers, such as Sethe or Eva Peace, whose terrible violations against their children can be seen as maternal acts of resistance against the oppressing patriarchal society, Sweetness' low self-esteem and selfhatred, and ergo her toxic motherhood, are the outcome of her internalization of the patriarchal racist discourse and her disconnection from the black "motherline." 4 The patriarchal institution of motherhood entraps her, revealing her powerlessness: "the power-relations between mother and child are often simply a reflection of power-relations in patriarchal society ... Powerless women have always used mothering as a channel ... to return upon the world what it has visited on them" (Rich 38).

In God Help the Child, Sweetness' family is an example of matrilineal transmission of racist ideologies and attitudes due to the rupture in the

\footnotetext{
${ }^{3}$ Brenda Daly and Maureen Reddy argue that only a limited number of fictional or theoretical texts, like Morrison's novels, deal with the mother's perspective (2).

${ }^{4}$ Motherline is a term that was first used by Naomi Lowinsky to refer to the ancient knowledge of women transmitted by female oral tradition. She thinks that female empowerment is only possible through the reconnection to the motherline (13).
} 
motherline. ${ }^{5}$ By means of Sweetness' female kins, Morrison poses the question about race and how the "Negro blood running and hiding in [your] veins" can shape your life and that of your offspring (3). African Americans have been historically defined according to the one-drop rule, which traces back to the time of slavery and was reinforced under the Jim Crow system. The one-drop rule, which characterized African Americans according to the amount of black blood they had-using terms such as quadroon (one-fourth African black), octoroon (one-eight African black), became the nation's social and legal definition of blacks and spread to all ambits of society. In front of a racist society, African Americans face a paradox connected to the dilemma of difference. They have to choose between assimilation or segregation. In the 1900s, segregation was still in force: blacks and whites were separated in transportation, churches, armed forces, schools, etc. Many blacks encountered all kinds of obstacles to full opportunity and participation and could not escape certain social hurdles without passing as white. Sweetness' mother, Lula Mae, who embraces her race, has to pay a price. She suffers segregation and discrimination in her daily life. Due to her light skin color, she could do things other blacks could not, such as trying on hats or using the ladies' room in department stores, however, when she gets married, she has to put her hand on the Bible reserved for blacks. Selfchosen segregation can lead African Americans to social exclusion, but it helps them preserve their own traditions and heritage and assert their identity.

On the other hand, those black individuals who passed for white endured the psychological trauma of denying who they really were, shunning their family and relations off their lives, confronting the fear of exposure, etc. Sweetness' grandmother stands for the stereotypical "tragic" mulatto that cuts off all ties with her black kin and community, so that she can pass for white. She never answered the letters that her relatives sent to her. As Morrison writes, "Almost all mulatto types and quadroons did that back in the day-if they had the right kind of hair" (3). Sweetness is light-skinned and her hair is "high yellow." She follows in her grandmother's footsteps. Sweetness expresses her internalized racism in her "colorism," the preference for light skin over dark skin, "Some of you probably think it's a bad thing to group ourselves according to skin color - the lighter, the better-in social clubs, neighborhoods, churches, sororities, even colored schools. But how else can we hold on to a little dignity?" (4). She has not grown among other black women that can pass on to her their black cultural values, instilling in her pride for her black self. Sweetness, who lives in a white-dominated racist urban environment, seems to have lacked, as a child and as an adult, the othermothering that rural black communities can provide.

Sweetness" "racially confused" self is disclosed when she sees her daughter, Lula Ann, for the first time. The exposure of her unmistakably African ancestry turns her world upside down. Sweetness cannot enforce a positive

\footnotetext{
${ }^{5}$ The matrilineal model provides "an alternative to the heterosexual family" and "a wholly different way for women to exist in the world" (Rich 85).
} 
mothering, fostering a meaningful racial identity in her child because of her selfcontempt. Like Jadine or her grandmother, she identifies herself with the values of the dominant culture. From the first moment her daughter is born, she knows "something was wrong. Really wrong" (3). She feels terribly embarrassed and scared when her baby's skin turns black, "Midnight black, Sudanese black" (3). She thinks her daughter's eyes have a blue tint with "something witchy about them" (6). Sweetness feels revulsion towards her own child, "nursing her was like having a pickaninny sucking my teat" (5), and even contemplates the possibility of killing her or giving her away to an orphanage.

Owing to racial discrimination and segregation, blacks have come to incorporate racist stereotypes, perceiving themselves according to the ideals of the white-dominated society. African Americans have embraced white aesthetics as desirable, since by mixing freely with whites the self-disgust inculcated in them would vanish. Assimilation would apparently let them enter the mainstream, a phenomenon that affects specially women who are judged by their straight hair or light skin. Black females need to be beautiful as defined by white society. Sweetness' attitude towards Lula Ann is a response to the hegemonic discourse of female beauty. She projects her self-hatred on her daughter, who exemplifies all those racial features Sweetness has learnt to hate: Lula Ann is too black ("terrible color"), her lips are "too-thick" and "her wild hair was always a trial" (42). As adults, mother and daughter are obsessed with their appearance, both living a superficial life: "Like Jadine, Bride is shallow, emotionally stunted, and enamored of the glitzy professional world she lives and works in" (Umrigar). Clothing and cosmetics are crucial aspects in their existence. Lula Ann remembers how her mother's bedroom always seemed unlit and her dresser was full of "grown-up-woman stuff" (tweezers, cologne, hairpins) (53), and Lula Ann herself actually makes it her way of life.

God Help the Child shows how racism promotes a patriarchal authoritarian parenting style. African American childrearing, Dr. Kerby Alvy (2011) writes, is usually more restrictive and authoritarian, which can be traced to blacks' history of slavery oppression and discrimination. A stricter parenting stylecorporal punishment or downplaying children's good qualities - allowed black parents to keep their offspring safe. Authoritarian parenting, characterized by its low warmth and high control, is associated with the institution of patriarchal motherhood, while one of the most important aspects of a positive mothering is nurturance. ${ }^{6}$ Only by loving your children can mothers empower them against racism and instill in them a loved sense of self, enabling them to confront and question racist discourses that define them as unworthy of love. J. D. McLeod and M. Shanahan (1993) argue how the mothers' lack of affection towards their infants increases their internalizing and externalizing behavior problems, such as low self-esteem and inferiority complexes, as they feel that they are not

\footnotetext{
${ }^{6}$ Diana Baumrind's very influential parenting typologies classify childrearing into three main groups according to warmth and control: authoritarian, authoritative, and permissive.
} 
'seen,' heard, or even loved.

Sweetness, with her ironic name, rears Lula Ann in a patriarchal authoritarian way. Lula Ann grows up bereft of affection and love, which destroys the mother-daughter bond. Patriarchal motherhood prevents Sweetness from developing the necessary emotional and affective ties with her daughter, critical during the first years of a child's life. Lula Ann remembers how her mother loathed touching her dark skin, "Distaste was all over her face when I was little and she had to bathe me" (31). Lula Ann also recalls how she made little mistakes deliberately so that her mother would touch her, but Sweetness found ways to punish her daughter without touching her hateful skin. Lula Ann actually feels glad when she soils her bed sheet with her first menstrual blood and her mother slaps her, being handled "by a mother who avoided physical contact whenever possible" (79). As an infant, Lula Ann misses being closer to her mother. She remembers hiding behind the door to hear Sweetness hum some blues song, thinking how nice it would have been if they could have sung together. Sweetness' withdrawal of affection is her daughter's worst memory. Lula Ann still recalls her mother's screaming or the look on her face when she spilled the Kool-Aid or tripped on the rug.

During her infancy, Lula Ann is desperately needy of love. That is why she testifies against a teacher, Sofia Huxley, and lies about her pervert abuses of children, "To get some love-from her mama" (156). Lula Ann remembers how Sweetness was "kind of motherlike" the day she points at Sofia, smiling at her and even holding her hand when they walked down the courthouse steps, which she had never done before. O'Reilly emphasizes how the oppressive institution of patriarchal motherhood often results in violence against children, which can be manifested in child neglect and abuse (From Motherhood 8). Sweetness neglects her maternal duties so as not to confront the rejection of society. She does not take Lula Ann much outside because those who see her baby in the carriage give a start or jump back before frowning. Neither does she want to be seen as her mother. Sweetness does tell her daughter to call her by her name, instead of "Mother" or "Mama," so people do not know they are related. She does not attend parent-teacher meetings or volleyball games either. The racial self-contempt that Sweetness, who has accepted an inferior definition of the black self, inculcates in her daughter does not allow her to have a sense of belonging or identity. Sweetness truly believes that no matter how many times Lula Ann changes her name, her skin color will be "a cross she will always carry" (7).

Authoritarian mothers use more often power-assertive techniques to discipline their children. They usually play higher value on obedience and are more likely to use physical punishment and more commands, without explaining them. Sweetness' patriarchal motherhood is about maternal control, compliance and conformity. She thinks that she has to be "Very careful in how [she] raise[s] her [daughter]. [She] had to be strict, very strict" (7). Sweetness has experienced racial discrimination first hand. She recalls witnessing a group of white boys bullying a black girl, so she trains Lula Ann to cross the street and avoid white 
boys. Sweetness believes that "There was no point in being tough or sassy even when you were right ... Lula Ann needed to learn how to behave, how to keep her head down and not to make trouble" (7). To help black children cope with racism, their parents teach them special skills (self-reliance, self-defense, dealing with pain and disappointment), however, Sweetness' motherhood only seeks absolute and uncontested obedience. She does not foster a positive racial identity in her daughter so she can resist racist practices, conversely, she imposes on her the societal cultural norms, values and expectations of the dominant culture. Lula Ann's upbringing and disciplining are really harsh and even more when she is turning an adolescent. Her rearing was all about following rules, which she obeyed: "I behaved and behaved and behaved" (32). And yet, Lula Ann feels that

she never knew the right thing to do or say or remember what the rules were. Leave the spoon in the cereal bowl or place it next to the bowl; tie her shoelaces with a bow or a double knot; fold her socks down or pull them straight up to the calf? What were the rules and when did they change? (78-79)

Other scholars stress socioeconomic conditions and structural inequalities, discrimination, as the main causes for African Americans' adaptive parenting techniques (Jarrett 31). Thusly, authoritarian parenting behaviors are tightly connected with a lower socioeconomic status. Parents living in precarious conditions are, V. C. McLoyd (1990) contends, less supportive of their children. When Lula Ann is born, Sweetness is scared that her husband, Louis, may accuse her of infidelity. The first words of this oeuvre are: "It's not my fault. So you can't blame me. I didn't do it and have no idea how it happened" (3). Lula Ann's birth brings about dire consequences, which change Sweetness' life. First, her husband does not accept the child, whom he treats "like she was a stranger-more than that, an enemy. He never touched her" (5). Louis cannot love his baby and runs out on them. As a result of the father's abandonment, Sweetness becomes the sole provider, facing both emotional and financial difficulties: "we see at once the financial and emotional pressure that childrearing places upon disadvantaged African-American mothers" (DeLancey 15). After her husband's desertion, Sweetness faces a bleak future, "I don't have to tell you how hard it is being an abandoned wife" (6). She has to stand the meanness of the welfare clerks, who treat her and her daughter like beggars until Louis starts sending her money once a month. These money orders and her night job at the hospital get them off welfare. Lula Ann becomes a heavy "burden" that Sweetness has to bear.

Among a myriad of co-variants (parent's education, family composition, teenage pregnancy, etc.), the type of family has been regarded as a relevant factor in parenting styles: "Many single parents ... find it difficult to function effectively as parents ... they are less emotionally supportive of their children, have fewer rules, dispense harsher discipline are more inconsistent in dispensing discipline, provide less supervision, and engage in more conflict with their children" (Hetherington \& Clingempeel). The one-parent family can be a key 
risk indicator associated with patriarchal maternal practices when, as in Sweetness' case, it is combined with the mother's self-loathing, a poor socioeconomic status and a surrounding racist society. ${ }^{7}$ In the $1900 \mathrm{~s}$, it was harsh for a colored single mother, even a light one, to lead an ordinary life, as for example, when Sweetness wants to rent a cheap apartment. Segregation is firmly established even if the law does not, allegedly, allow discrimination. African Americans were legally protected when renting, nevertheless, landlords would make up excuses not to admit black tenants. Even when Sweetness eventually finds a place, she is charged more for it than it had been advertised. ${ }^{8}$ Sweetness has to meet the challenge of raising alone a black kid in a racist society "where you could be sent to a juvenile lockup for talking back or fighting in school ... where you'd be the last one hired and the first one fired [where] her black skin would scare white people or make them laugh and trick her" (41). In addition to a highly trying environment, child-rearing stress has been linked to the father's absence, which leaves the parenting exclusively to the mother. Fathers and fathering are part of the nurturing that guarantees children's psychological growth: "there must be shared responsibility [both parents], for the child to begin to approach wholeness" (Samuels \& HudsonWeems 75).

And despite all the suffering, Sweetness' "protective" motherhood cannot preserve her daughter from the "curse" that starts with Mr. Leigh's insults when Lula Ann sees him abusing a boy. He calls her "nigger" and "cunt." Lula Ann, who is only six years old, does not need the definitions of the words because she feels the hate and revulsion they are charged with. Just like, later at school, when other curses are hissed or shouted at her, bad names, ape sounds or monkey mimicry. Lula Ann learns her mother's lessons and "let the namecalling, the bullying travel like poison, like lethal viruses through [her] veins, with no antibiotic available ... buil[ding] up immunity so tough that not being a 'nigger girl' was all [she] needed to win" (57). Sweetness' authoritarian patriarchal motherhood does not focus on meeting Lula Ann's cultural and emotional needs. She is more concerned about her daughter living up to the standards, norm-abiding ideas, consensus values and expectations of the whitedominated racist society. When Lula Ann has to testify, her mother is very nervous thinking that her daughter's performance may put her to shame, instead of being worried about her stressful situation.

Sweetness fails to fulfill the three essential tasks of maternal practice,

\footnotetext{
${ }^{7}$ The Moynihan Report (1965) revealed that the majority of African American parents raising their children were single mothers. The percentage of black children brought up in single-parent homes has grown even more since then, from 20 percent to 70 percent, while only about 30 percent have both parents (Toldson).

${ }^{8}$ Sweetness tells Lula Ann not to say a word about the child abuse perpetrated by their landlord she has witnessed because "it would be hard finding a location in another safe, meaning mixed, neighborhood" (54).
} 
without which the child will not be able to confront racial injustices or develop a strong sense of black selfhood. Deprived of affection, effective preservation and cultural bearing, Lula Ann has to struggle her whole life for self-definition, trying to protect herself from being hurt. At the age of sixteen, she drops out of high school and flees home. Lula Ann changes her "dumb countrified name" and calls herself Bride. She builds a new life for herself, escaping from her mother's and society's definitions. Bride reinvents herself. She becomes the regional manager of a prosperous cosmetics business, Sylvia Inc., and leads a glamorous life. Bride "stitche[s] together: personal glamour, control in an exciting even creative profession, sexual freedom and most of all a shield that protect[s] her from any overly intense feeling" (79). Being a successful woman, she finds vengeance in selling her elegant blackness to her childhood ghosts, her tormentors, so they can feel envious of her triumph. Notwithstanding, as Bride says, her failures in adult life (her breakup with Booker, her boyfriend, or being beaten by Sofia Huxley) make her realize that, in spite of her mother's strict lessons, she is helpless in the presence of confounding cruelty: she just obeyed, she "never fought back." She feels that she is "too weak, too scared to defy Sweetness, or the landlord, or Sofia Huxley" (79).

All along the novel, the extent of the harm Sweetness' patriarchal motherhood has inflicted in Bride is exposed. Her traumatic childhood experiences keep surfacing. Her lost identity is symbolized by the physical regression, "back into a scared little black girl" (142), triggered by Booker's rejection: losing her pubic and underarm hair, her ear piercings, her breasts. Bride's self-confidence and boldness are just an appearance, "thrillingly successful corporate woman façade of complete control" (134), as the products she sells, while she is really needy of love and acceptance. She becomes conscious that "she had counted on her looks for so long-how well beauty worked. She had not known its shallowness or her own cowardice-the vital lesson Sweetness taught and nailed to her spine to curve it" (151). Bride's bungled attempt to make amends for the terrible lie she told as a child does not work out the way she expects and her breakup with Booker - to whom she had "spilled [her] heart" (62)—along with his hurtful words, "You not the woman I want" shatter her (10). She feels "Dismissed" and "Erased" (38).

Bride sets out in search of her boyfriend on a quest for self-realization and self-forgiveness. During her recovery from a car accident in northern California, she has time to think. She realizes that "she had been scorned and rejected by everybody all her life" (98). Her encounter with Queen makes her feel as if she had been stripped of her beauty and glamour and taken back to the time when "she was the ugly, too-black little girl in her mother's house" (144). She remembers Booker's rational words about race, which are "contradicted" by blacks' day-to-day experience:

'It's just a color,' Booker had said. 'A genetic trait—not a flaw, not a curse, not a blessing nor a sin.'

'But,' she countered, 'other people think racial_-' 
Booker cut her off. 'Scientifically there's no such thing as race, Bride, so racism without race is a choice. Taught of course, by those who need it, but still a choice. Folks who practice it would be nothing without it.' (143)

In rural California, Bride also meets Rain, a semi-feral girl who has suffered terrible abuse on her mother's hands, a rendezvous that "conjures her repressed feelings of racial rejection" (Sturgeon 2015). Their short true companionship and Bride's genuine attempt to save the child are a healing experience for her, a true act of restitution. Finally, she confronts Booker and her confession to him makes her feel newly born: "No longer forced to relive, no, outlive the disdain of her mother and the abandonment of her father" (162). Bride tells him about her pregnancy and he offers her "the hand she had craved all her life, the hand that did not need a lie to deserve it, the hand of trust and caring for" (175). At the end of the novel, Bride acquires, apparently, the sense of self required to mother her baby and not to reproduce Sweetness' toxic mothering: "A child. New life. Immune to evil or illness, protected from kidnap, beatings, rape, racism, insult, hurt, self-loathing, abandonment ... So they [Bride and Booker] believe" (175). There is hope in the ending of this "brisk modernday fairy tale with shades of the Brothers Grimm" (Walker 2015).

In the last chapter, Morrison discloses Sweetness as a sick guilt-ridden woman in a nursing home. She wants to believe that she had raised her daughter to cope with the harsh reality black people had to face and states: "I wasn't a bad mother" (43). And yet, her words, "But it's not my fault. It's not my fault. It's not my fault. It's not" (7), a prayer or chant, seem to convey her concealed feelings of guilt at her patriarchally distorted motherhood. Sweetness excuses her lack of affection blaming her challenging circumstances and tells herself that her lessons have paid off, as when her daughter makes her proud "as a peacock" in the trial. And yet, Sweetness admits that she could not love her blue-black baby, even if she does now, and also recognizes that she may have done hurtful things to her only child, "All the little things [she] didn't do or did wrong" (177). There is regret beneath Sweetness' words, however, she does not seem able to take full responsibility for the damage she has inflicted on her daughter. Nevertheless, as Roxane Gay claims, “it is difficult to judge Sweetness's choices. She should know better, but is painfully clear her choices have been shaped by the realities of being black in a white world - a world where the lighter your skin, the higher you might climb."

The blunt moral of God Help the Child is that "What you do to children matters. And they might never forget" (43). Morrison's latest novel puts the spotlight on toxic mothering, "describing the devastation, both personal and cultural, that arises when children are not preserved, nurtured, or do not receive cultural bearing ... [Morrison] stress[es] the crucial importance of mothering by showing the loss and suffering that occurs in its absence" (O'Reilly, Toni Morrison 172). Culture-bearing maternal love is critical to the formation of the black children's proud selfhood and their empowerment, so they can develop survival and resistance strategies to face and subvert the racist world they live in. In contrast 
to the cycle of abuse, molestation and violation of children this narrative unveils, Morrison envisions a hopeful future in Bride's mothering as a potential site of empowerment of children in the face of racism (and sexism).

\section{WORKS CITED}

Alvy, Kerby. The Soulful Parent: Raising Healthy, Happy and Successful African American Children. The Center for The Improvement, 2011.

Baumrind, Diana. "Effects of Authoritative Control on Child Behavior." Child Development, 37 (1966): 887-907.

Collins, Patricia Hill. Black Feminist Thought: Knowledge, Consciousness, and the Politics of Empowerment. New York: Routledge, 1991.

---. "The Meaning of Motherhood in Black Culture and Black MotherDaughters." Double Stitch: Black Women Write About Mothers and Daughters. Eds. Patricia Bell-Scott, et al. New York: Harper Perennial, 1993: 42-60.

Daly, Brenda and Maureen Reddy. Narrating Mothers: Theorizing Maternal Subjectivities. Knoxville: Tennessee UP, 1991.

DeLancey, Dayle. 'Motherlove is a Killer: 'Sula,' 'Beloved,' and the Deadly Trinity of Motherlove.” SAGE: Scholarly Journal on Black Women 7.2 (1990): 15-18.

Gay, Roxane. "God Help the Child by Toni Morrison Review-'Incredibly Powerful'." The Guardian. 29 April. 2015. Web. 17 Oct. 2015. $<$ http://www.theguardian.com/books/2015/apr/29/god-help-the-childtoni-morrison-review-novel $>$.

Hetherington, Mavis and W. Glenn Clingempeel. "Coping with Marital Transitions." Journal of Marriage and the Family. 54 (1992): 368-78.

Jarret, Robin. "African American Children, Families, and Neighborhood: Qualitative Contributions to Understanding Developmental Pathways. Applied" Developmental Science. 2 (1998): 2-16.

Lowinsky, Naomi. The Motherline: Every Woman's Journey to Find her Female Roots. Los Angeles: Tarcher, 1992.

McLeod, J. D. and M. Shanahan. "Poverty, parenting, and children's mental health." American Sociological Review. 58 (1993): 351-66.

McLoyd, V. C. "The Impact of economic Hardship on Black Families and Children: Psychological Distress, Parenting, and Socioemotional Development." Child Development 61 (1990): 311-46.

Morrison, Toni. The Bluest Eye. New York: Holt, Rinehart, and Winston, 1970.

---. Sula. New York: Alfred Knopf, 1973.

---. Song of Solomon. New York: Signet, 1978. 
---. Tar Baby. New York: New American Library, 1981.

---. Beloved. New York: Plume, 1987.

---. A Mercy. New York: Alfred Knopf, 2008.

---. God Help the Child. New York: Alfred Knopf, 2015.

O'Reilly, Andrea. Toni Morrison and Motherhood: A Politics of the Heart. New York: SUNY Press, 2004a.

---. From Motherhood to Mothering: The Legacy of Adrienne Rich's Of Woman Born. New York: SUNY Press, 2004b.

Rich, Adrienne. Of Woman Born: Motherhood as Experience and Institution. New York: Norton, 1986.

Samuels, Wilfred and Clenora Hudson-Weems. Toni Morrison. Boston: Twayne, 1990.

Sturgeon, Jonathon. "Toni Morrison is Not Your Grandmother: On the Explosive, Alienating God Help the Child." Flavorwire. April 16. 2015. Web. 5 Oct. 2015. <http://flavorwire.com/514546/toni-morrisonis-not-your-grandmother-on-the-explosive-alienating-god-help-thechild $>$.

Toldson, Ivory. "Single Parents Aren't the Problem." The Root. July 3. 2013. Web. 6 June 2015. $<$ http://www.theroot.com/articles/culture/2013/07/singleparent househ olds_and_black_children_education_not_affected_as_much_as_you_th ink.html >.

Umansky, Lauri. Motherhood Reconceived: Feminism and the Legacies of the Sixties. New York: New York UP, 1996.

Umrigar, Thrity. "God Help the Child by Toni Morrison.” Boston Globe. April 18. 2015. Web. 82015. $<$ https://www.bostonglobe.com/arts/books/2015/04/18/book-reviewgod-help-child-tonimorrison/MGA5UlhUJ9vG7dseNPnHGO/story.html>.

Walker, Kara. "Toni Morrison's God Help the Child." The New York Times. April 13. 2015. Web. $10 \quad$ Oct. 2015. $<$ http://www.nytimes.com/2015/04/19/books/review/toni-morrisonsgod-help-the-child.html?_r=0>.

Washington, Teresa N. "The Mother-Daughter Àje Relationship in Toni Morrison's Beloved.” African American Review. 39.1/2 (2005): 171-88.

Wilson, Judith. "'The Language Must Not Sweat:' A Conversation with Toni Morrison." Conversations with Toni Morrison. Ed. Danille TaylorGuthrie. Jackson: Mississippi UP, 1994. 119-28.

Received: 17 July 2015 Accepted: 6 November 2015 